\title{
Exchange of Microfilm Orders
}

A T THE 1943 annual meeting of the American Documentation Institute it was agreed that provision for exchange of orders among major research libraries would be very desirable.

As a result of this meeting, a committee was appointed to arrange for exchange of microfilm orders among a selected group of research libraries. The committee consists of: William H. Kenerson, National Research Council; Waldo G. Leland, American Council of Learned Societies; and Ralph R. Shaw, United States Department of Agriculture Library, chairman.

Two major problems in enabling scholars to receive microfilm with a minimum of delay and effort are: (I) provision of a uniform price schedule that would be acceptable to the cooperating libraries and (2) provision of a simple mechanism for exchange of orders.

The following libraries have agreed to cooperate in a plan for exchange of microfilm requests for periodical articles for a six-month experimental period starting Mar. I, 1944: Army Medical Library, Washington, D.C. ; Brown University Library, Providence, R.I.; Columbia University Libraries, New York City; Denver Public Library, Denver; Harvard College Library, Cambridge, Mass.; Library of Congress, Washington, D.C.; New York Public Library, New York City ; HowardTilton Memorial Library, Tulane University, New Orleans; United States Department of Agriculture Library, Washington, D.C.; University of Washington Library, Seattle; Yale University Library, New Haven, Conn. At the end of this period they will report results of the experiment to the American Documentation Institute in order that the value of the program may be appraised in the light of experience.

The agreement under which this experiment is being conducted is as follows:

\section{Purpose}

Exchange of microfilm orders for periodical articles which cannot be supplied directly by the library from which they were originally ordered.

\section{Method of Operation}

Each of the cooperating libraries shall continue to supply all microfilm copies of articles that it would normally supply on orders that it receives. Any order which it cannot supply will be forwarded to any one of the cooperating libraries which can supply it instead of returning it to the person requesting the material, and the cooperating library will supply the film required direct to the customer.

Price: The price charged for copying under this cooperative arrangement shall be fifty cents for any article in one volume of a periodical.

Upon receipt of an order which cannot be filled in one of the cooperating libraries, the cooperating library may either forward the original request to any other of the cooperating libraries which can supply the service or may keep the original order in its file, sending a memorandum to any of the cooperating libraries which can supply the service, indicating the service desired and by whom desired. In either case the forwarding library will notify the person requesting the microfilm that his inquiry has been forwarded to the other library 
and refund his payment, if any.

Upon receipt of the order, the cooperating library to which it is forwarded may either send an estimate, requesting payment in advance, or may furnish the reproduction together with a bill for the service, if that is in accordance with its policy.

\section{General Provisions}

It is agreed that each cooperating library:

I. May limit the number of periodical articles it will copy under this agreement.

2. Reserves the right to refuse any order which requires more than fifteen minutes of reference work.

3. Reserves the right to refuse any order which does not conform to its own copying policy.
4. Will perform the work requested or report upon it within two weeks from the date of receipt of the order.

5. Will verify each reference it sends to another library and will not transmit any order unless there is evidence that the library to which it is forwarded has the material requested (i.e., as shown in the Union List of Serials or other guides to holdings).

6. Will reserve the right to supply photoprints, if it elects to do so, in lieu of microfilm in those cases in which photoprints can be supplied for fifty cents.

7. Reserves the right to limit the length of any article supplied for fifty cents under this agreement to not more than fifty pages, if it wishes to do so.

Ralph R. Shaw

\section{Librarians and Current Research Publication}

(Continued from page 243)

White, Carl M. "The Battle of the Books." (In Vital Speeches, Mar. I, 1944, p. 316-20.)

"H. G. Wells, writing just after the last war, described the situation of humanity at that time as a race between education and catastrophe. As we all know, catastrophe won the race. But if the United Nations win this war, education has one more chance.... If we lose the next race, the next catastrophe will be a bigger and better catastrophe which might close this phase of the development of the human species. ..."-Page 320.

Finally, the waging of the battle of books has a bearing on public policy. It falls outside my present purpose to describe how intellectual or cultural services relied on so heavily by the modern world unofficially can better be fitted into the framework of official policy. But the conclusion that public action normally follows pretty closely the thinking of literate people, and that the thinking of literate people normally follows the most powerful intellectual forces of the times, has some inescapable implications. It implies a policy of recognizing and systematically developing intellectual leadership of high order. It implies a policy of protecting and supporting all those professionally concerned with ideas who show intellectual integrity and a sense of public responsibility. It implies a policy of keeping accessible to the public the sources of information-the press, the open forum, and that increasingly important source of all kinds of information, the modern library.-Page 320. 